\title{
Strategies to Improve Teacher Ability in Using The Madrasah E-Learning Application During the COVID-19 Pandemic
}

\author{
Dedi Riyan Rizaldi ${ }^{1 *}$, Aris Doyan ${ }^{1}$, Ziadatul Fatimah $^{1}$, Muhamad Zaenudin $^{2}$, Muhammad Zaini ${ }^{3}$ \\ ${ }^{I}$ Master of Science Education, Postgraduate Program, University of Mataram, Indonesia \\ ${ }^{2}$ Madrasah Aliyah Plus Nurul Islam Sekarbela, Mataram, Indonesia \\ ${ }^{3}$ Masters in Islamic Religious Education, Postgraduate Program, Mataram State Islamic Institute, Indonesia \\ *Corresponding author e-mail: dedi0313@gmail.com | Whatsapp Number: +62-82339483147
}

Manuscript received 23 Feb 2021; revised 2 March. 2021; accepted 15 March 2021. Date of publication 2 April 2021

\begin{abstract}
Learning during a pandemic requires every teacher to be able to improve literacy skills in terms of using technology to help the learning process. However, due to the rapid paradigm shift due to the COVID-19 pandemic, from direct learning to online-based learning. Therefore this activity was carried out to improve the ability of Madrasah Aliyah Plus Nurul Islam Sekarbela teachers in using various learning support applications, especially the Ministry of Religion E-learning. The Ministry of Religion E-learning application is an application recommended by the Ministry of Religion of the Republic of Indonesia for use in the distance learning process during the COVID-19 pandemic at the madrasa level. The use of applications in the learning process is expected to be able to increase student motivation and enthusiasm for learning during the learning period from home and still pay attention to health protocols. Participants in this activity were attended by all teachers who teach at Madrasah Aliyah Plus Nurul Islam with a total of 36 people. In its implementation, this activity consists of three stages, namely 1 . The preparation stage, 2. Implementation stage, and 3. Evaluation stage with each activity an evaluation process is carried out to ensure that the initial objectives of this activity can be achieved. Based on the activities that have been carried out, it can be concluded that this mentoring activity is needed by teachers in understanding the use of the Ministry of Religion E-learning application with various supporting features and its implementation. Also, after carrying out this activity, teachers began to get used to the use of the Ministry of Religion's E-learning application in carrying out the learning process during the COVID-19 pandemic.
\end{abstract}

Keywords: Madrasah E-learning Application, Distance Learning, COVID-19 Pandemic.

\section{Introduction}

Teachers are one of the factors that concern all circles because their role in the world of education is very important. This has to do with preparing human resources to face the various challenges that arise in the future, especially during the COVID-19 pandemic, which is currently happening in most countries. This pandemic was caused by the Corona Dieses Virus. The thing that makes this virus dangerous is the very fast nature of its spread so that people who like to gather in crowded places will have the opportunity to be infected by this virus [1]. This has led several countries to establish policies to impose lockdowns to prevent the spread of the coronavirus [2]. Indonesia is one of the countries affected by the COVID-19 pandemic in all areas of life including the education sector. So that the government is required to issue a social distancing or physical distancing policy to minimize or break the chain of spreading COVID-19 in the community. Social distancing carried out by local governments greatly impacts the conditions of learning in each educational unit [3], [4]. The impact on the education sector causes a paradigm of the learning process that previously occurred directly or face-to-face in the classroom, then turned into learning that takes place online [5], [6]. The learning paradigm is very necessary for current conditions to achieve the goals of national education in educating the nation's life. This is because the success or failure of a nation is very dependent on Human Resources (HR) which will be produced through a continuous learning process. However, it is this drastic change that makes most teachers a little difficult because they are not used to doing the learning process online using various platforms or other learning applications. Literacy in the use of technology is very important in supporting the learning process that is occurring during the current COVID-19 pandemic. Without participating in technology, it will be very difficult to do the learning process because of limitations in terms of socializing or gathering in one place.

According to Ozerbas \& Erdogan (2016), the application of technology during the COVID-19 pandemic in all fields has increased drastically, one of which has been affected, namely in the field of education [7]. The educational process is very influential on technological developments in the field of technology [8]. The availability of technology in the form of both hardware and software is one of the factors that influence the learning process. Educational technology must be able to bridge the good wishes between teachers and students. The rapid development of technology has given rise to many devices that can be used easily to help teachers and students. One of them that can 
support online learning is by using a smartphone, where the tool can be installed with online learning support applications, which can make it easier for teachers and students to interact.

Madrasah Aliyah Plus Nurul Islam is one of the private schools that since the beginning of COVID-19 has decided to eliminate the direct learning process in schools and implement an online learning system. Online learning is a learning system that is carried out by utilizing technology facilities and the like in delivering information [9]. This learning system allows the learning process to occur in conditions anytime and anywhere as long as the parties concerned have a network of connections. This was done to reduce the possibility of spreading the COVID-19 virus in the school environment both during the learning process or in other conditions. The main application that is used as a reference in online learning carried out at Madrasah Aliyah Plus Nurul Islam is using the Ministry of Religion's E-learning application. E-Learning is a form of information technology applied in education in the form of a website that can be accessed by any internet network [10], [11]. E-learning is the basis and logical consequence of the development of information and communication technology. With Elearning, learners or students do not need to sit nicely in the classroom to listen to every word from a teacher directly, everything can be accessed through E-learning.

Madrasah E-learning is one of the application media provided by the Ministry of Religion of the Republic of Indonesia to facilitate teachers and students at the madrasah level so that the learning process continues. Apart from using Madrasah E-learning, the entire teacher council also uses the WhatsApps group. However, based on the implementation for three months since the implementation of the online learning system, it is seen that not all Madrasah Aliyah Plus Nurul Islam teachers use the Madrasah E-learning application. This is due to the lack of socialization regarding the procedures for using E-learning applications in the learning process. Most teachers and students find it difficult to use this application so that the WhatsApps group is the most used media during the learning process that occurs in the even semester of the 2019/2020 school year. Based on the above problems, it is deemed necessary to carry out a mentoring activity to introduce the various features contained in the Madrasah E-learning application as well as how to use them in the learning process in the classroom. This activity is one of the strategies carried out by the school so that in the future learning process teachers can use various applications, especially Madrasah E-learning so that learning becomes more active and effective when compared to only using the WhatsApp group.

\section{Method}

This mentoring activity was carried out during the learning period for the 2020/2021 academic year at Madrasah Aliyah Plus Nurul Islam Sekarbela. The main target of this activity is all teachers who teach at MA Plus Nurul Islam. This activity consists of three stages, namely preparation, implementation, and evaluation. This activity focuses on accompanying teachers in using the Madrasa E-learning application during the teaching and learning process during the COVID-19 pandemic, which is difficult to allow face-to-face learning.

\section{Results and Discussion}

\subsection{Result}

Assistance activities for the use of the Madrasah E-learning application have been carried out at Madrasah Aliyah Plus Nurul Islam Sekarbela to increase teacher virtual innovation towards creative and innovative learning during the COVID-19 pandemic. Assistance activities for the use of the Madrasah E-learning application were attended by the entire teaching board totaling 36 people. Based on the results of the evaluation, it can be seen that there is an increase in the use of the Madrasah E-learning application in the teaching and learning process that occurred in the semester of the 2020/2021 school year when compared to the previous academic year, precisely at the beginning of the implementation of online learning. The following is a comparison chart of the use of the Madrasah E-learning application by the Madrasah Aliyah Plus Nurul Islam Sekarbela teaching board after mentoring for approximately 6 months. In addition to seeing the active use of the Madrasah E-learning application in the learning process, data was also obtained on the reasons for some of the teaching boards who were not active in using the application in delivering their learning material to students, following the classification of some of these reasons

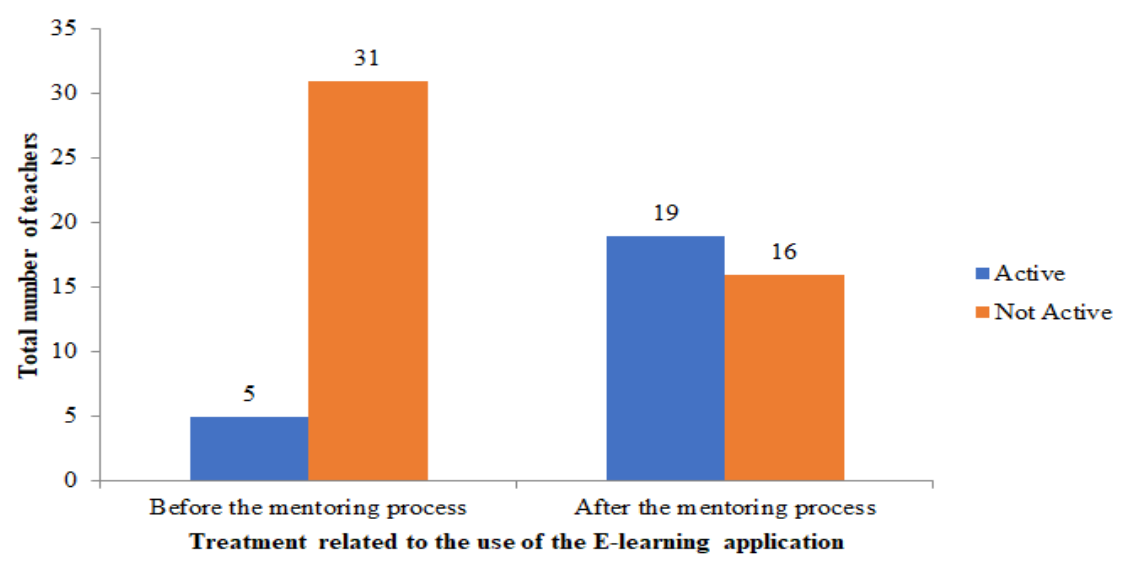

Fig 1. Madrasah E-learning Application Usage Comparison Chart 


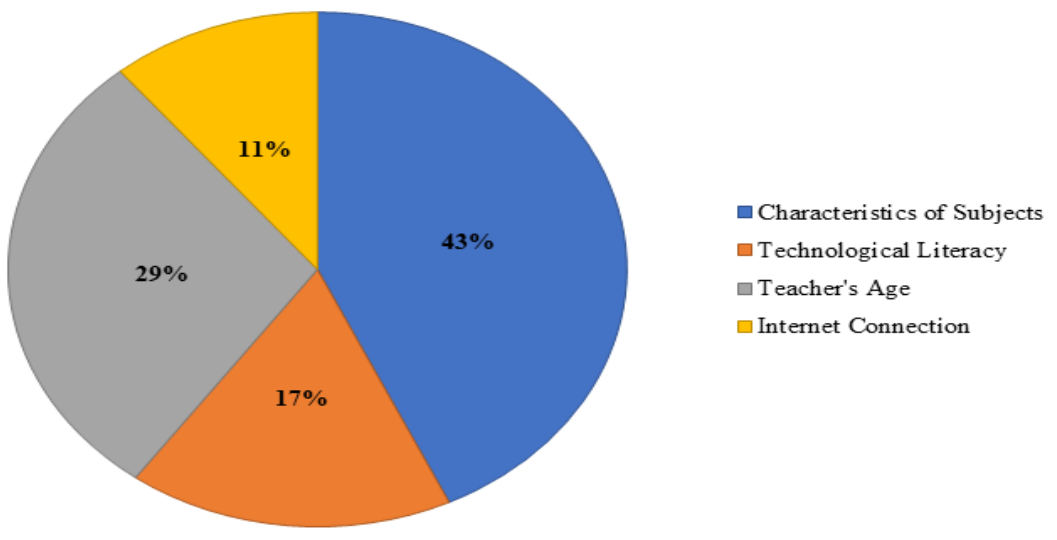

Fig 2. Madrasah E-learning Application Use Factors in the Learning Process

\subsection{Discussion}

The preparatory stage begins by making observations related to the results of the learning evaluation in the 2019/2020 semester, where it appears that the learning process has not been maximized because many teaching boards have not used the Madrasah E-learning application to support the teaching and learning process. During this period most of the teaching boards only used WhatsApps Group (WAG) to convey learning information so that the interaction between teachers and students could not be maximized because the nature of learning was only limited to giving assignments without material delivery. According to Rizaldi, et al. (2020) that the delivery of material in a learning process has a good impact on students in understanding certain concepts that cannot be studied independently [12]. Therefore, assistance was provided to the entire teaching board of Madrasah Aliyah Plus Nurul Islam Sekarbela to use the Madrasah E-learning application in the learning process for approximately 6 months (July-December 2020), precisely during the semester learning period 2020/2021. This use is in line with the direction of the Ministry of Religion of the Republic of Indonesia which recommends all madrasah teaching boards to use the application.

The implementation stage is carried out with two activities, namely the Madrasah E-learning application workshop to provide an initial overview to the entire teaching board regarding the various features in the application to be used in supporting the online teaching and learning process.

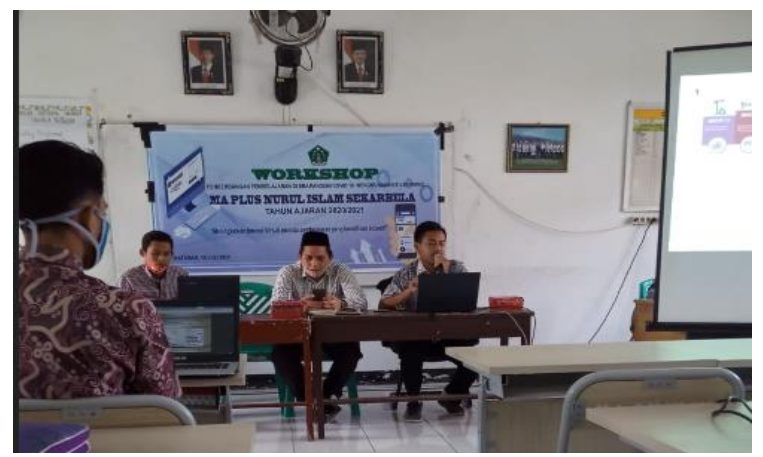

Fig 3. Workshop on the Use of Madrasah E-learning Applications

Based on the workshop activities, it is known that the Madrasah E-learning application has several advantages where all activities that occur in the learning process at madrasah will be directly monitored both by the school principal, madrasah supervisors, and others parties. With a system like this, of course, it provides opportunities for all parties, especially schools to carry out an evaluation process at any time regarding the achievement of the expected learning goals [13]. Also, the advantages of this application are that it makes it easy for teachers to arrange learning tools and evaluation tools [14]. This is because this application provides several features on the class timeline such as

1. Video Conference which can be used for video call-based learning.

2. Competency standards are used as a reference for teachers in carrying out the learning process.

3. Minimum completeness criteria can assist teachers in formulating minimum student achievement values after going through the learning and assessment process.

4. Teaching materials are used to provide learning resources to students in various formats such as word, pdf, excel, PowerPoint, internet link, etc.

5. The assessment consists of several choices such as CBT (Computer Based Test), knowledge assessment, and skills assessment.

6. And several other supporting features.

All features in this application are designed to be as easy as possible so that teachers do not experience difficulties in the process of preparing and implementing learning during the COVID-19 pandemic. It's just that besides having advantages, of course, this application has several drawbacks, including the login process into the application, sometimes having problems. This is possible because this application is used by all levels of madrasah in Indonesia. Also, several features in this application that are not yet optimal, such as the 
maximum limit of teaching material files that can be uploaded by teachers is only $2 \mathrm{MB}$. The procedure for using the Madrasah E-learning application for teachers, among others.

1. Login using the username and password provided by the school operator using the appropriate link provided by the school. Each school has a different link and is directly connected to the central system.

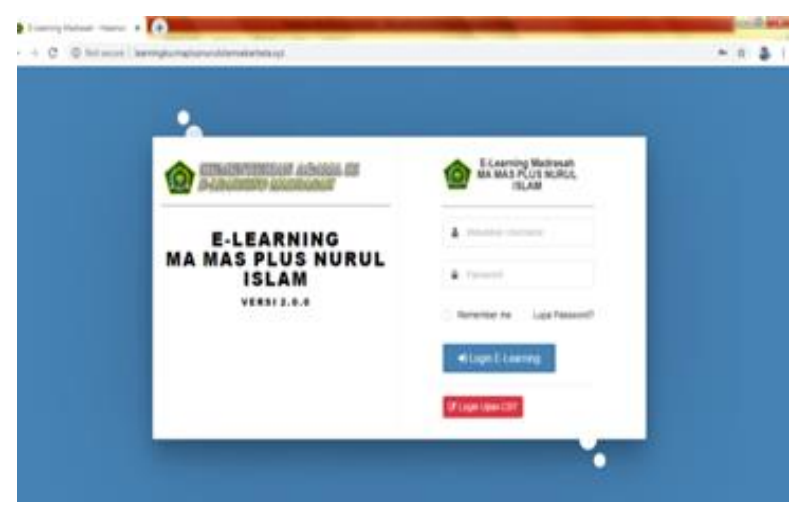

Fig 4. Login Page

2. Fill in the attendance list on the homepage of the school group timeline.

3. Creating online classes consisting of teachers and students according to the subject matter.

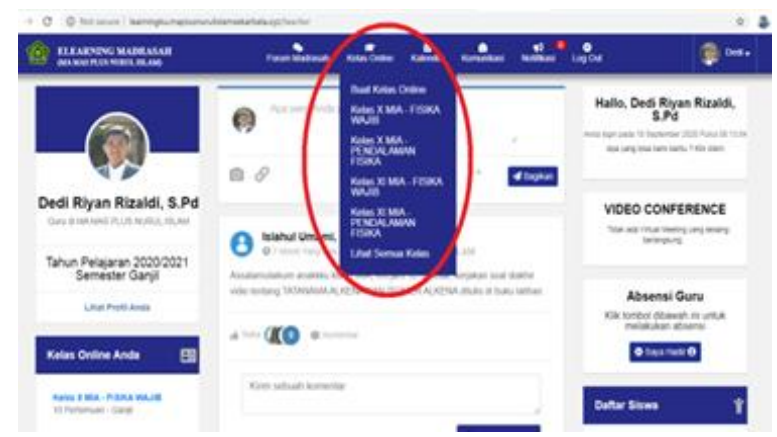

Fig 5. Features of the Madrasah E-learning Application

4. Inviting students to enter the online class by with student data that has been provided by the madrasah operator.

5. Fill in Competency Standards consisting of Core Competencies and Basic Competencies by the learning syllabus that is the reference for each subject.

6. Determine minimum completeness criteria by the objectives to be achieved by students.

7. Prepare a learning process plan.

8. Share teaching materials that students can download. The teaching material files provided should be in the form of a pdf or a learning video link so that they can be easily opened by students.

9. Prepare an evaluation process in the form of assignments, daily tests, semester exams, etc. using the system features of the Computer Based Test (CBT), Knowledge Assessment, or Skills Assessment.

10. Monitor student activities using the student activity monitoring feature in the Madrasah E-learning application.

The second activity at the implementation stage is assistance to the entire teaching board to apply the information that has been obtained regarding the Madrasah E-learning application in the online learning process. To support this activity, the school facilitates facilities in the form of computers in madrasah that teachers can use to implement learning using the Madrasah E-learning application.

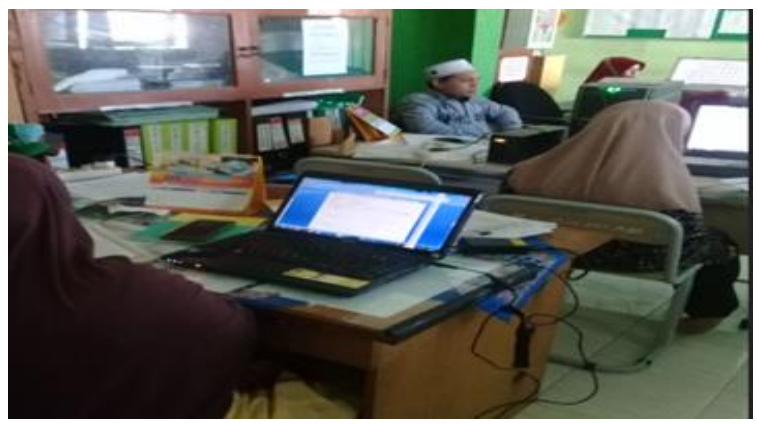

Fig 6. Assistance Activities for the Use of Madrasah E-learning Applications in the Online Learning Process

Teachers only need to come to the madrasah according to their respective teaching schedules, which will be guided by several other teachers who have mastered the use of the application. The mentoring activity starts from the process of providing online classrooms, developing online learning tools, using the Jitsi Meet feature to conduct video conferences with students, and the assessment process in the form of 
assignments, daily tests, and others. With this process, madrasas can directly observe the course of the learning process as well as the various deficiencies faced by teachers while implementing the Madrasah E-learning application.

The final stage is the evaluation which is carried out after the teaching and learning process at Madrasah Aliyah Plus Nurul Islam is completed at the end of the semester. Based on Figure 1., it can be seen that there is an increase in the use of the Madrasah E-learning application by teachers in supporting the teaching and learning process during the COVID-19 pandemic. This increase certainly has a positive impact on schools, teachers, and students in improving the quality of the learning process [15]. This is because the various features of the Madrasah E-learning application make it easier for teachers to convey information and carry out the online assessment process. It is hoped that after carrying out mentoring activities for approximately 6 months, teachers will continue to use the Madrasah E-learning application and various other learning applications so that students do not feel bored in following the learning process during the COVID19 pandemic, which does not allow face-to-face learning as before. This is in line with research conducted by Insiyah (2019) and Sahlani, et al. (2020) which states that the use of the Madrasah E-learning application can increase the effectiveness of the learning process without having to face to face in madrasah [16], [17].

In addition to seeing the level of teacher participation in using the Madrasah E-learning application, an unstructured interview process was carried out to the entire teaching board of Madrasah Aliyah Plus Nurul Islam regarding supporting factors for using the Madrasah Elearning application in the learning process. This interview activity was carried out to evaluate, especially for the committee, to improve the learning process implementation system in the next semester if the government was still implementing an online learning system. Based on these activities, it was found that the highest factor related to not using Madrasah E-learning applications in the learning process was the characteristics of the subjects at $43 \%$. Some teachers, especially those who teach subjects in the religious field, think that it is very difficult to convey religious learning material through various learning applications. Religious learning will be more meaningful if it is delivered directly in front of students. Also, the age factor is a problem in implementing Madrasah E-learning applications. Teachers over 30 years of age find it very difficult to operate the Madrasah E-learning application at home without assistance, such as when it is done at school. This factor will relate to the digital literacy level of teachers in using various technologies in the learning process. However, overall the assistance activities for the use of the Madrasah E-learning application received a good response from the entire teaching board at Madrasah Aliyah Plus Nurul Islam Sekarbela. Besides being able to improve the quality of learning, this activity also provides new insights for teachers in managing the learning process during the COVID-19 pandemic.

\section{Conclusion}

Based on the background and discussion, it can be concluded that this mentoring activity is needed by teachers in understanding the use of the Madrasah E-learning application and its application in the learning process during the COVID-19 pandemic. The teacher gets an overview of the various features and their respective functions that can make it easier to help teachers to keep the distance learning process going. The use of Madrasah E-learning applications generally consists of several stages, namely 1). Creating online classrooms, 2). Inviting students to enter the online class, 3). Preparing teaching materials, 4). Completing basic competencies, 5). Doing online learning, and 6). Evaluating the learning process.

\section{Acknowledgment}

Gratitude is extended to all teaching staff, especially Mr. Muhamad Zaenudin, S.Pd as the Head of Madrasah Madrasah Aliyah Plus Nurul Islam who has facilitated the author in carrying out mentoring activities in order to improve the ability of Madrasah Aliyah Plus Nurul Islam teachers to use the Madrasah E-learning application in the learning process during the pandemic COVID-19. Hopefully, this activity can be useful especially for teachers in supporting the distance learning process.

\section{References}

[1] N. R. Yunus and A. Rezki, "Kebijakan Pemberlakuan Lock Down Sebagai Antisipasi Penyebaran Corona Virus Covid-19," SALAM J. Sos. dan Budaya Syar-i, vol. 7, no. 3, pp. 227-238, 2020, doi: 10.15408/sjsbs.v7i3.15083.

[2] F. E. Alvarez, D. Argente, and F. Lippi, “A Simple Planning Problem for COVID-19 Lockdown,” Natl. Bur. Econ. Res., no. 26981, pp. 1-35, 2020, [Online]. Available: http://www.nber.org/papers/w26981.

[3] Gunawan, N. M. Y. Suranti, and Fathoroni, "Variations of Models and Learning Platforms for Prospective Teachers During the COVID-19 Pandemic Period," Indones. J. Teach. Educ., vol. 1, no. 2, pp. 61-70, 2020.

[4] E. Nurhayati, D. R. Rizaldi, and Z. Fatimah, "Pencegahan Penyebaran COVID-19 Melalui Inaktivasi Virus dalam Kajian Kinetika, Termodinamika, dan Kesetimbangan,” J. Ilm. Profesi Pendidik., vol. 5, no. 2, pp. 102-107, 2020, doi: 10.29303/jipp.v5i2.121.

[5] D. Riyan Rizaldi and Z. Fatimah, "Penggunaan Aplikasi Zoom Cloud Meeting pada Mata Kuliah Mekanika dan Termostatistika saat Pandemi COVID-19," Kappa J., vol. 4, no. 2, pp. 225-232, 2020, doi: 10.29408/kpj.v4i2.2237.

[6] N. K. Suni Astini, "Tantangan Dan Peluang Pemanfaatan Teknologi Informasi Dalam Pembelajaran Online Masa Covid-19," Cetta J. Ilmu Pendidik., vol. 3, no. 2, pp. 241-255, 2020, doi: 10.37329/cetta.v3i2.452.

[7] M. A. Ozerbas and B. H. Erdogan, "The Effect of the Digital Classroom on Academic Success and Online Technologies SelfEfficacy,” Int. Forum Educ. Technol. Soc., vol. 19, no. 4, pp. 203-212, 2016, doi: 103.133.160.5.

[8] D. R. Rizaldi, E. Nurhayati, and Z. Fatimah, "The Correlation of Digital Literation and STEM Integration to Improve Indonesian Students' Skills in 21 st Century,” Int. J. Asian Educ., vol. 1, no. 2, pp. 73-80, 2020, doi: 10.46966/ijae.v1i2.36.

[9] A. Prajana, "PEMANFAATAN APLIKASI WHATSAPP DALAM MEDIA PEMBELAJARAN DI UIN AR-RANIRY BANDA ACEH," Cybersp. J. Pendidik. Teknol. Inf., vol. 1, no. 2, pp. 122-133, 2017, doi: 10.22373/cs.v1i2.1980.

[10] S. R. Chandrawati, "PEMAMFAATAN E-LEARNING DALAM PEMBELAJARAN," J. Cakrawala Kependidikan Vol., vol. 8, no. 2, pp. 172-181, 2010.

[11] P. Sari, "Memotivasi Belajar Dengan Menggunakan E-Learning," J. Ummul Quro, vol. 6, no. 2, pp. 20-35, 2015, [Online]. Available: http://ejournal.kopertais4.or.id/index.php/qura/issue/view/531. 
[12] D. R. Rizaldi, Z. Fatimah, M. Hasanah, Faisal, and S. Handayani, "Pembelajaran Berbasis Berugak Pintar Untuk Meningkatkan Minat Belajar Anak di Desa Dasan Lekong," J. Pengabdi. Masy. Sains Indones., 2020.

[13] T. Wasyik and A. Hamid, "Implementasi E-Learning Dalam Pembelajaran Alquran Era COVID-19 Di Sanggar Tahfidz Entrepreneur Krian Sidoarjo,” EDUDEENA J. Islam. Relig. Educ., vol. 4, no. 1, 2020.

[14] S. Hikmah, "Pemanfaatan e-learning Madrasah dalam Pelaksanaan Pembelajaran Jarak Jauh Masa Pandemi di MIN 1 Rembang," Edutrained J. Pendidik. dan Pelatih., vol. 4, no. 2, pp. 73-85, 2020, doi: http://doi.org/10.37730/edutrained.v4i2.81.

[15] D. R. Rizaldi and Z. Fatimah, "How the Distance Learning can be a Solution during the Covid-19 Pandemic," Int. J. Asian Educ., vol. 1, no. 3, pp. 117-124, 2020, doi: 10.46966/ijae.v1i3.42.

[16] S. J. Insiyah, "E-Learning Madrasah Dan Solusi Pembelajaran Di Tengah-Tengah Pandemi Covid-19," Khazanah:Jurnal Edukasi, vol. 2, no. 2, pp. 139-147, 2020.

[17] L. Sahlani, D. Sopiansyah, and B. Agung, "Pemanfaatan kegiatan pembelajaran dalam jaringan (e-learning) dalam menghadapi masa pandemi covid-19 di madrasah aliyah negeri 2 bandung," J. Al-Ibanah, vol. 05, no. 02, pp. 152-191, 2020. 